\section{Influence of Daughter Plant Weight and Position on Strawberry Transplant Production and Field Performance in Annual Plasticulture}

Fumiomi Takeda ${ }^{1}$

Appalachian Fruit Research Station, Agricultural Research Service, U.S. Department of Agriculture, 2217 Wiltshire Road, Kearneysville, WV 25430

Stan C. Hokanson ${ }^{2}$

Department of Horticultural Science, 258 Alderman Hall, University of Minnesota, St. Paul, MN 55108

\section{John M. Enns ${ }^{3}$}

Fruit Laboratory, Building 010A, Beltsville Agricultural Research Center, Agricultural Research Service, U.S. Department of Agriculture, 10300 Baltimore Avenue, Beltsville, MD 20705

Additional index words. stolon, soilless culture, plug plant, rooting, propagation

Abstract. Strawberry ('Chandler') plants were grown in a greenhouse hydroponic culture system from 28 Apr. to 20 July to produce runners (stolons) with several daughter plants. By mid-July, each 'Chandler' plant had developed about 30 daughter plants on 12 runners with 1 to 6 daughter plants on each runner. Daughter plants varied in weight from $<0.9$ to $>10 \mathrm{~g}$. Daughter plant weight and position on the runner affected new root development on plug plants during the first 7 days under mist irrigation. At 3 weeks, $87 \%$ of daughter plants that weighed $<0.9 \mathrm{~g}$ and at least $96 \%$ of daughter plants that weighed $>1.0 \mathrm{~g}$ were rated acceptable for field transplanting, respectively. The percentage of daughter plants from second to tenth node position that were rated acceptable for field planting ranged from $98 \%$ to $88 \%$, respectively. Runner production in the fall was not affected by either position on the runner or weight at the time of daughter plant harvest. But, larger daughter plants produced more branch crowns than did smaller daughter plants in the fall. Transplant survival in the field was $100 \%$. In the spring, 'Chandler' plants produced a $10 \%$ greater yield from daughter plants that weighed $9.9 \mathrm{~g}$ compared to those that weighed only $0.9 \mathrm{~g}$.

In the eastern United States, strawberries have been produced in a perennial, matted-row culture system, established in the spring with dormant cold stored plants (Galletta and Bringhurst, 1990). Beginning in the early 1990's, growers in several states in the mid-Atlantic coast region became interested in the annual plasticulture system (Fiola et al., 1995; Poling, 1993), and production in this system has grown to more than 1,800 ha in 12 states in the South Atlantic (excluding Florida), Middle Atlantic and Midwest regions (personal communication, E.B. Poling). This system has relied almost entirely on plants established in late summer using cultivars (e.g., 'Camarosa', 'Chandler', and 'Sweet Charlie') developed by strawberry breeders in California and Florida. The performance of cold-stored, dormant transplants in plasticulture has not been entirely satisfactory because of poor field establishment (Poling

Received for publication 20 Feb. 2004. Accepted for publication 1 Apr. 2004. We gratefully acknowledge the technical assistance provided by Ann K. Hummell and Kate Salazar.

${ }^{1}$ Research horticulturist. To whom requests for reprint should be addressed; e-mail ftakeda@afrs. ars.usda.gov.

${ }^{2}$ Assistant professor; e-mail hokan017@umn.edu. ${ }^{3}$ Horticulturist; e-mail ennsj@ba.ars.usda.gov. sources are fresh-dug, bare-root plants from nurseries in Canada and North Carolina or plug plants generated from harvested runner tips. The Canadian nursery industry supplies bare root plants to growers in the southeastern United States. These plants are only available from mid-September to mid-October, which is too late for the preferred planting dates in mid-August to early September for the Middle Atlantic coast and Midwest regions. There is a need to produce substantial quantities of runner tips for plug plant production for the mid-summer to late-summer establishment period preferred for the annual plasticulture production system in the region (Hokanson and Finn, 2000).

Recently, we described research conducted on production of runner tips by eastern US cultivars using soilless, hydroponic systems to generate container plants needed for an August planting date to establish eastern strawberry cultivars in an annual plasticulture system (Hokanson et al., 2004; Takeda et al., 2000; Takeda and Hokanson, 2002). In those studies, mature runner tips were harvested weekly from May to July from mother plants growing hydroponically in rain gutters with a recirculating nutrient solution and cold stored and Durner, 1986). Alternative transplant for 0,1 , and 2 months. The field performance of transplants generated from cold-stored runner tips was not affected by storage durations, but runner tips stored as long as 2 months at 1 ${ }^{\circ} \mathrm{C}$ had a reduced capacity to develop advantitious roots when they were stuck in cell packs and misted intermittently. Bish et al. (2001) described a greenhouse system to produce large quantities of 'Oso Grande' and 'Sweet Charlie' strawberry plantlets for plug production, but did not address the field performance of the transplants.

Here, we describe another runner tip harvest technique for production of daughter plants in 'Chandler' strawberry. This strategy involved the one time harvest in mid-July of all the runners. The objectives were 1) to characterize the capacity of 'Chandler' mother plants in a hydroponic system to develop runners and daughter plants and 2) to evaluate daughter plants harvested from runners for root formation under mist sprinkler and field performance in annual plasticulture system.

\section{Materials and Methods}

Plant materials. In this study, we used 'Chandler' strawberry, a 1983 University of California release (Voth and Bringhurst, 1984). 'Chandler' strawberry is the most widely used cultivar in the annual eastern production system outside Florida (Poling, 1993). Tissue-cultured plantlets maintained at the USDA Fruit Laboratory in Beltsville, Md., were the source stock for plant material used in this study. In January 1999 single explants of 'Chandler' strawberry were subcultured onto Stage II strawberry shoot proliferation media described by Swartz et al. (1981). Subsequent plant handling methods and growing conditions used to produce plants for this study are presented elsewhere (Hokanson et al., 2004, Takeda and Hokanson, 2002).

Greenhouse culture. On 27 Apr. 1999, plants were established in nutrient film technique (NFT) culture using $10.2 \mathrm{~cm}$ polyvinyl chloride (PVC) gutters (Genova Products, Inc., Davison, Mich.), suspended $2 \mathrm{~m}$ above the greenhouse floor in a N-S orientation. The gutters were sloped slightly by hanging the south end of the 4.7-m long gutter about $15 \mathrm{~cm}$ higher than the north end to allow nutrient to flow over the length of the gutter. The gutters were filled with coarse horticultural perlite (Geiger Co., Harleysville, Pa.). The mother plants were allowed to develop primary stolons until 20 July, and all secondary stolons that developed laterally from daughter plants on the primary stolons were pinched.

The nutrient solution consisted of ChemGro (5-15-25) Strawberry Formula (HydroGardens, Inc., Colorado Springs, Colo.) with supplemental calcium nitrate and magnesium sulfate held in a 760-L tank. The nutrient solution was delivered to each gutter using a drip emitter $\left(7.6 \mathrm{~L} \cdot \mathrm{h}^{-1}\right)$ at the high end of the gutter for $15 \mathrm{~min}$ at $2 \mathrm{~h}$ intervals. Excess nutrient solution drained out at the lower end of the gutter and returned to the tank. A controller (Cole-Parmer Instrument Co, Vernon Hills, Ill.) was used to maintain the solution $\mathrm{pH}$ at 6.2 with 
injection of phosphoric acid. The volume of nutrient solution was maintained at a constant level by daily addition of tap water. At 10- to 14-d intervals when the volume of added tap water reached $760 \mathrm{~L}$ the nutrient solution was discarded and a new batch was added to the tank. The greenhouse was maintained at $23 \pm$ $5^{\circ} \mathrm{C}$ day and $18 \pm 5^{\circ} \mathrm{C}$ night temperatures and photoperiod was extended to $16-\mathrm{h}$ by activating $1,000 \mathrm{~W}$ HPS lamps $\left(115 \sim 135 \mu \mathrm{M} \cdot \mathrm{m}^{-2} \cdot \mathrm{s}^{-1}\right.$ at plant canopy height) during predawn hours.

All runners were detached from mother plants on 20 July and daughter plants on each runner were counted. Daughter plants were then removed from runners with a minimum of five daughter plants and grouped by their node positions or chronological age (2nd, 4th, 6 th, etc.) on the runner. Ten randomly selected daughter plants from each node position were weighed. The remaining daughter plants were combined and sorted into the following fresh weight classifications: very light $(<0.9 \mathrm{~g})$, light (between 1.0 and $2.5 \mathrm{~g}$ ), medium (between 2.5 and $4.0 \mathrm{~g}$ ), heavy (between 4.0 and $6.0 \mathrm{~g}$ ), and very heavy (>6.0 g).

Plug plant production. Daughter plants were rooted in 72-cell packs filled with soilless media (Sunshine \#5 Plug Mix, Sun Gro Horticulture, Elizabeth City, N.C.) and the trays were placed under micro-sprinklers programmed to mist plants for $10 \mathrm{~s}$ every 6 min. After 1 week, the cycle was changed to mist $10 \mathrm{~s}$ every $12 \mathrm{~min}$ for another 2 weeks. At 1 week, 10 plants were gently pulled out of rooting media to count new roots formed at the node and from adventitious roots. The length of the longest root on each daughter plant was measured. After 3 weeks on the rooting bench, daughter plants were pulled out of cell packs to determine whether daughter plants had developed enough root mass to hold the media intact.

Field establishment of plug plants. On 12 Aug. 1999, the plug plants were established in a field at USDA-ARS, Beltsville Agricultural Research Center, Beltsville, Md. The soil was a Elkton Keyport silt loam that was prepared with a $10 \bullet 10 \bullet 10$ preplant $\mathrm{N}-\mathrm{P}-\mathrm{K}$ fertilizer applied at $34 \mathrm{~kg} \cdot \mathrm{ha}^{-1}$ ). The planting system consisted of raised beds, about $15 \mathrm{~cm}$ high and $81 \mathrm{~cm}$ wide, mulched with 1.1-mil embossed black plastic (Trickl-eez Co., Biglerville, Pa.). The raised beds were spaced $1.5 \mathrm{~m}$ apart from center to center. The plots were irrigated with a 10 mil T-Tape plastic drip system with emitters at $30.5 \mathrm{~cm}$ spacing and a flow rate of 1.71 $\mathrm{L} \cdot \mathrm{min}^{-1}$ per 30.5-m capacity (Trickl-eez Co., Biglerville, $\mathrm{Pa}$.), that was installed $5 \mathrm{~cm}$ under the soil when the black plastic was applied. The plants were arranged in offset double row spaced $30 \mathrm{~cm}$ between and within rows with six plant plots. The experiment was a randomized complete block design with four replications for each treatment. The planting was maintained with weekly applications of $11.3 \mathrm{~kg} \cdot \mathrm{ha}^{-1}$ of soluble nitrogen (ammonium nitrate), applied through the drip irrigation for 5 weeks following planting. At first growth flush the following spring, the first of four weekly applications of $8.5 \mathrm{~kg} \cdot \mathrm{ha}^{-1}$ of ammonium nitrate was applied through the drip irrigation system.
No fungicide or insecticides were applied to the planting and weed management was accomplished by hand at various times for the duration of the experiment.

In September and October 1999, runner and branch crown numbers were recorded for each plant. Runners were removed at each count in a manner similar to commercial annual-culture field management. During the winter, plots were covered with straw mulch. In Spring 2000 , all ripe strawberries were harvested twice weekly from the plots. At each harvest, the following data were collected; total plot yield, average weight of 10 randomly selected fruit, and a subjective rating of marketable yield based on the percentage of small, misshapen, diseased or damaged fruit, with 9 representing all fruit considered marketable and 1 representing no marketable fruit (Galletta et al., 1995). Subsequently, data for the number of picks, the season of production, expressed as the percent of fruit harvested in the first two pickings, plant yield, and average fruit size for the season were calculated.

Statistical analysis. Data were analyzed for treatment differences using SAS Proc mixed model analysis (SAS Institute Inc., Cary, N.C.). Calculated percentage values were transformed using arcsine of the square root of the percentage value. Treatment means were then separated using a DIFF option in the Proc Mixed Model.

\section{Results and Discussion}

One-time harvest of multiple-daughter runners. Each 'Chandler' mother had produced about 12 runners with 2 to 6 daughter plants per runner by 20 July. There was an average of 30 daughter plants for each mother plant. In this study, all secondary runners that developed laterally from daughter plants on the primary runners were pinched. In another study in which these lateral runners were not pinched, 'Chandler' mother plants produced 80 daughter plants after 12 weeks from the start of the experiment (Takeda, unpublished observation). Recently, Bish et al. (2001) reported that 'Oso Grande' mother plants produced 84 daughters in two harvests at 8 and 16 weeks from planting in the greenhouse. These studies and other reports (Boxus et al., 1984) show that large quantities of plants can be produced from tissue-cultured strawberry plants. However, the weight of daughter plants may vary and all daughter plants may not be viable for transplanting success.

A wide range in daughter plant weight $(<1.9$ $\mathrm{g}$ to $>10 \mathrm{~g}$ ) was recorded (Tables 1 and 2) with the average weight declining with increasing node position (Table 1). Correspondingly, maximum petiole lengths ranged from $11 \mathrm{~cm}$ to $2.6 \mathrm{~cm}$ for the heaviest to the lightest daughter plants (data not presented). Daughter plants produced by this production technique were more mature than the runner tips collected weekly from May to July in a companion study (Hokanson et al., 2004; Takeda and Hokanson, 2002). In those studies, runners were harvested when the daughter plant at the 2 nd node showed early signs of adventitious root development at its base (Poling and Parker, 1990). In the present study, daughter plants except for the most distal had already developed as many as 20 adventitious roots by mid-July. As a result, daughter plants with excessive roots were not easily planted into individual cell packs with rooting media. Increased labor efficiency and production of quality transplants are major concerns for plant nurserymen when considering a plant propagation system.

After 1 week on the rooting bench significant differences in new root numbers were observed between daughter plant positions and in root length between daughter plants of different weight classes (Tables 1 and 2). However, root number or length noted at one week (Tables 1 and 2) did not appear to singularly affect root growth by week 3 on the rooting bench. Production of field transplantable plants within three weeks was improved by using daughter plants harvested from the node most proximal to the mother plants than those from more distal nodes. Percentage of daughter plants that developed adequate root mass for field transplanting ranged from $98 \%$ for daughter plants from 2 nd node to $88 \%$ for daughter plants from 10th node. The results suggested that less mature and smaller daughter plants have reduced capacity to develop a sufficient root mass to hold the rooting media intact when the plant was pulled out of propagation cells. More than $96 \%$ of the daughter plants in the light to very heavy $(\geq 1.7 \mathrm{~g})$ categories developed into transplantable plug plants, but only $87 \%$ of daughter plants that weighed $\approx 0.9 \mathrm{~g}$ developed into transplantable plug plants after three weeks on the rooting bench. Poor root formation affects the efficiency of the plant production scheme. A propagation efficiency of $<90 \%$ on the rooting bench is unacceptable to strawberry plant nurserymen (David Lankford, Davoncrest Farms, Hurlock, Md., personal communication). The results suggested that daughter plants weighing $<1.5$ $\mathrm{g}$ should be discarded.

Field performance. Transplants grew vigorously in the field. No plant loss was recorded during the first three months in the field (data not presented). Daughter plant size or position on the runner had no effect on runnering in the field (Table 3). All plants produced about 10 runners by late October. Excessive runner production in the fall is considered a negative trait (Battey et al., 1998; O'Dell and Williams, 2000). Newer annual production systems being adapted worldwide are designed with yields based on high density planting (43,000 plants/ha) of multi-crowned plants that produce large numbers of flowers. In such systems, runner production has been characterized as having an antagonistic relationship with flowering (Battey et al., 1998). Runner removal in the fall results in higher yields the following spring (Hancock et al., 1982). Fall runner removal is a recommended operation in annual strawberry production system (O'Dell and Williams, 2000).

Daughter plants sized as very heavy or heavy doubled their crown numbers to two by late October (Table 3). Plants derived from daughter plants sorted as small or very 
Table 1. Weight at harvest, root formation and plug formation into transplantable plants by daughter plants harvested from node $2,4,6,8$, and 10 of primary runners of 'Chandler' plants.

\begin{tabular}{llccc}
\hline Node & $\mathrm{Wt}$ & \multicolumn{2}{c}{ Root formation } & \begin{tabular}{c} 
Plug formation \\
\cline { 3 - 5 } position
\end{tabular} \\
\cline { 3 - 5 } & $(\mathrm{g})$ & No. & Length $(\mathrm{cm})^{\mathrm{y}}$ & $(\%)$ \\
\hline Second & $6.7 \mathrm{a}^{\mathrm{x}}$ & $16.8 \mathrm{~b}$ & $4.0 \mathrm{a}$ & $98 \mathrm{a}$ \\
Fourth & $4.8 \mathrm{~b}$ & $17.9 \mathrm{ab}$ & $4.3 \mathrm{a}$ & $94 \mathrm{a}$ \\
Sixth & $2.9 \mathrm{c}$ & $20.5 \mathrm{a}$ & $4.6 \mathrm{a}$ & $94 \mathrm{a}$ \\
Eighth & $2.3 \mathrm{c}$ & $15.1 \mathrm{ab}$ & $5.2 \mathrm{a}$ & $92 \mathrm{a}$ \\
Tenth & $1.5 \mathrm{~d}$ & $15.1 \mathrm{a}$ & $88 \mathrm{a}$ \\
\hline
\end{tabular}

${ }^{2}$ Values represent the percentage of daughter plants that had developed a cohesive rootball and did not fall apart when gently lifted from the cell pack. Transplants were rated after 3 weeks on the rooting bench. Percentage values were arcsine transformed and then subjected to Proc Mixed statistical procedure.

${ }^{y}$ Average values of the longest adventitious root measured in each plantlet $7 \mathrm{~d}$ after rooting.

${ }^{x}$ Mean separation within columns by DIFF option of SAS Proc Mixed, $P=0.05$

Table 2. Weight, root formation and plug formation into transplantable plants by daughter plants harvested from primary runners and sorted into five weight categories.

\begin{tabular}{llccc}
\hline \multirow{2}{*}{$\begin{array}{l}\text { Wt } \\
\text { category }\end{array}$} & Wt & \multicolumn{2}{c}{ Root formation } & $\begin{array}{c}\text { Transplant } \\
\text { production } \\
(\%)^{\mathrm{y}}\end{array}$ \\
\hline Very heavy & $(\mathrm{g})$ & No. & Length $(\mathrm{cm})^{\mathrm{z}}$ & $96 \mathrm{ab}$ \\
Heavy & $9.9 \mathrm{a}^{\mathrm{x}}$ & $16 \mathrm{a}$ & $3.8 \mathrm{~b}$ & $98 \mathrm{a}$ \\
Medium & $4.9 \mathrm{~b}$ & $14 \mathrm{a}$ & $4.3 \mathrm{~b}$ & $98 \mathrm{a}$ \\
Light & $2.8 \mathrm{c}$ & $18 \mathrm{a}$ & $4.5 \mathrm{ab}$ & $96 \mathrm{ab}$ \\
Very light & $1.7 \mathrm{~cd}$ & $17 \mathrm{a}$ & $5.5 \mathrm{a}$ & $87 \mathrm{~b}$ \\
\hline
\end{tabular}

${ }^{2}$ Average values of the longest adventitious root measured in each plantlet $7 \mathrm{~d}$ after rooting.

${ }^{y}$ Values represent the percentage of daughter plants that had developed a cohesive rootball and did not fall apart when gently lifted from the cell pack. Transplants were rated after 3 weeks on the rooting bench. Percentage values were arcsine transformed and then subjected to Proc Mixed statistical procedure.

${ }^{x}$ Mean separation within columns by DIFF option of SAS Proc Mixed, $P=0.05$.

Table 3. Effect of daughter plant weight and position on runner and branch crown numbers in October 1999 and harvest in spring 2000 for 'Chandler' plants in a plasticulture production system.

\begin{tabular}{lcccc}
\hline $\begin{array}{l}\text { Daughter } \\
\text { plant } \\
\text { category }\end{array}$ & $\begin{array}{c}\text { Stolons } \\
\text { (No./plant) }\end{array}$ & $\begin{array}{c}\text { Branch } \\
\text { crowns } \\
\text { (no./plant) }\end{array}$ & $\begin{array}{c}\text { Yield } \\
\text { (kg/plant) }\end{array}$ & $\begin{array}{c}\text { Fruit } \\
\text { size } \\
(\mathrm{g})\end{array}$ \\
\hline $\begin{array}{l}\text { Weight } \\
\quad \text { Very heavy }\end{array}$ & $11 \mathrm{a}^{\mathrm{z}}$ & $2.0 \mathrm{a}$ & $0.82 \mathrm{a}$ & $13.5 \mathrm{a}$ \\
$\quad$ Heavy & $10 \mathrm{a}$ & $2.0 \mathrm{a}$ & $0.77 \mathrm{ab}$ & $14.0 \mathrm{a}$ \\
$\quad$ Medium & $10 \mathrm{a}$ & $1.7 \mathrm{ab}$ & $0.75 \mathrm{~b}$ & $14.9 \mathrm{a}$ \\
Light & $10 \mathrm{a}$ & $1.6 \mathrm{~b}$ & $0.80 \mathrm{ab}$ & $14.6 \mathrm{a}$ \\
$\quad$ Very light & $10 \mathrm{a}$ & $1.5 \mathrm{~b}$ & $0.75 \mathrm{~b}$ & $14.9 \mathrm{a}$ \\
Position & $11 \mathrm{a}$ & & & $13.0 \mathrm{~b}$ \\
$2^{\text {nd }}$ node & $9 \mathrm{a}$ & $1.8 \mathrm{a}$ & $0.72 \mathrm{a}$ & $14.2 \mathrm{ab}$ \\
$4^{\text {th }}$ node & $10 \mathrm{a}$ & $1.7 \mathrm{a}$ & $0.73 \mathrm{a}$ & $14.5 \mathrm{a}$ \\
$6^{\text {th }}$ node & $10 \mathrm{a}$ & $1.4 \mathrm{a}$ & $0.76 \mathrm{a}$ & $14.1 \mathrm{ab}$ \\
$8^{\text {th }}$ node & $10 \mathrm{a}$ & $1.6 \mathrm{a}$ & $0.73 \mathrm{a}$ & $13.5 \mathrm{ab}$ \\
$1^{\text {th }}$ node & & $0.72 \mathrm{a}$ & $\mathrm{M}$ \\
\hline
\end{tabular}

${ }^{2}$ Mean separation within daughter plant categories and columns by DIFF option of SAS Proc Mixed. Means followed by the same letter are not significantly different $(P=0.05)$.

light developed fewer branch crowns during the same time. The node position of daughter plants had no effect on fall branch crown development. Early season vegetative growth and crown development during flower bud differentiation is reported to result in a more productive strawberry plant (Strik and Proctor, 1988).

Fruit harvest began on 11 May 2000, and continued twice weekly until 8 June, all ripe strawberries were harvested from the plots. The number of picks (nine harvests), early season yield $(27 \%)$, large fruit size $(>20 \mathrm{~g})$, and the marketable yield score (6.3) were not affected by daughter plant weight or their position on the runner. Significant effect of daughter plant weight but not their position on the runner was observed for plant yield (Table 3). Yield was about $10 \%$ greater for plants in plots established with heavier daughter plants than for plants in plots established with daughter plants weighing $\leq 0.9 \mathrm{~g}$. Fruit size was not affected by the weight of daughter plants for producing transplants. In contrast, small but significant treatment differences for average fruit size were observed among plants in plots established with daughter plants from different node positions (Table 3 ).

This study evaluated the potential of onetime harvest of daughter plants from 'Chandler' mother plants growing in soilless culture system to produce high numbers of runner tips by mid July for transplant. Each mother produced about 30 daughter plants on primary runners after 12 weeks in a greenhouse hydroponic system. All daughter plants except very small ones or those from the most distal nodes developed into field-ready transplants after 3 weeks on the rooting bench. It is more likely that plug plants generated from small daughter plants will be discarded in the field because of poor root development. However, among 'Chandler' transplants that were established in the field, no more than a $10 \%$ difference in vegetative growth and yield components were observed among five weight classes or node positions of daughter plants. Plug transplants produced from these daughter plants would be available during the narrow planting window (mid-August to early-September) for the colder production areas of the eastern seaboard and midwestern United States when the fresh-dug strawberry nursery plants from Canada and high-elevation nurseries in California are not available.

Economic analysis of various components of the greenhouse hydroponic system for onetime harvest of daughter plants is critically needed to determine whether this system can be considered an economically acceptable option for commercial strawberry propagators More runners can be produced from mother plants derived directly from tissue culture than field grown mother plants and a greenhouse system will permit establishment of mother plants at higher density $\left(\approx 9\right.$ plants $\left./ \mathrm{m}^{2}\right)$, but the cost of tissue cultured mother plants would be much higher than standard mother plants. Also, the ease of handling daughter plants with many pre formed roots is problematic. Greenhouse production techniques permit nurserymen to produce runner tips in an environment in which insect pests can be excluded and it would be possible to produce disease free clean plants. Using this technique, nurseries could generate transplantable plug plants for grower fields within six months after the plantlets are taken out of a sterile, in vitro environment and grown out in the greenhouse to produce runners. In a typical field nursery production system, a twoyear multiplication phase is needed to produce dormant, bare-root plants. When producing stolons and transplants in a protected environment is combined with a shorter propagation phase the potential of exposing plants to insects that transmit viruses is reduced significantly (Durner et al., 2002; Maas, 2000). Another advantage of this system is that phytosanitary concerns for soil fungal pathogens, nematodes, and insects encountered in field nurseries is reduced, thus circumventing the need for methylbromide soil fumigation.

\section{Literature Cited}

Battey, N.H.,P.LeMiere, A. Tehranifar, C. Cekic, S. Taylor, K.J. Shrives, P. Hadley, A.J. Greenland, D. Darby, and M.J. Wilkinson. 1998. Genetic and environmental control of flowering in strawberry, p. 111-131. In: K.E. Cockshull, D. Gray, G.B. Seymour, and B. Thomas (eds.). Genetic and environmental manipulation of horticultural crops. CAB Intl. Publ. Cambridge, U.K.

Bish, E.B., D.J. Cantliffe, and C.K. Chandler. 2001. A system for producing large quantities of greenhouse-grown strawberry plantlets for plug production. HortTechnology 11:636-638.

Boxus, P., C. Damiano, and E. Brasseur. 1984. Strawberry, p. 453-486. In: D.A. Ammirato, P.V. Evans, W.R. Sharp, and Y. Yamada (eds.). Handbook of plant cell culture. vol. 3. Crop species. Macmillan, New York.

Durner, E.F., E. B. Poling, and J.L. Maas. 2002. Recent advances in strawberry plug transplant technology. HortTechnology 12:545-550.

Fiola, J.A., R.J. Lengyen, and D.A. Reichert. 1995. Planting density and date affect productivity and profitability of 'Chandler', 'Tribute', and 'Tri- 
star' in strawberry plasticulture. Adv. Strawberry Res. 14:49-52.

Galletta, G.J. and R.S. Bringhurst. 1990. Strawberry management, p. 83-156. In: G.J. Galletta and D.G. Himelrick (eds.). Small fruit crop management, Prentice-Hall Inc., Englewood Cliffs, N.J.

Galletta, G.J., J.L. Maas, J.M. Enns, A.D. Draper, J.A. Fiola, J.C. Scheerens, D.D. Archibold, and J.R. Ballington. 1995. 'Northeaster' strawberry. Adv. Strawberry Res. 14:73-78.

Hancock, J., J. Siefker, N. Schulte, and M.P. Pritts. 1982. The effect of plant spacing and runner removal on twelve strawberry cultivars. Adv. Strawberry Prod. 1:1-3.

Hokanson, S.C. and C.E. Finn. 2000. Strawberry cultivar use in North America. HortTechnology 10:94-106.

Hokanson, S.C., F. Takeda, J.M. Enns, and B.L. Black. 2004. Influence of storage duration on strawberry runner tip viability and field performance. HortScience 39(7):1596-1600.

Maas, J.L. 2000. Opportunities to reduce the potential for disease infection and spread with strawberry plug plants. Acta Hort. 513:409-414.

O'Dell, C.R. and J. Williams. 2000. Hill system plastic mulched guide for colder areas. Va. Tech. (Blacksburg) Va. Coop. Ext. Publ. 438-18

Poling, E.B. 1993. Strawberry plasticulture in North Carolina: II. Preplant, planting, and postplanting considerations for growing 'Chandler' strawberry on black mulch. HortTechnology 3:383-393.

Poling, E.B. and E.F. Durner. 1986. Annual strawberry hill cultural system in southeastern North Carolina. HortScience 21:240-242.

Poling, E.B. and K. Parker. 1990. Plug production of strawberry transplants. Adv. Strawberry Prod. 9:37-39.

Strik, B.C. and J.T.A. Proctor. 1988. The importance of growth during flower bud differentiation to maximizing yield in strawberry genotypes. Fruit Var. J. 42:45-48

Swartz, H.J., G.J. Galletta, and R.H. Zimmerman. 1981. Field performance and phenotypic stability of tissue culture-propagated strawberries. J. Amer. Soc. Hort. Sci. 106:667-673.

Takeda, F. and S.C. Hokanson. 2002. Effects of transplant conditioning on 'Chandler' strawberry performance in a winter greenhouse production system, p. 132-135. In: S.C. Hokanson and A.R. Jamieson (eds.). Strawberry research to 2001. ASHS Press, Alexandria, Va.

Takeda, F., S. Hokanson, and J. Enns. 2000. Hydroponic strawberry runner-tip production. Proc. 2000 Mid-Atlantic Fruit Veg. Conf., p. 103-105.

Voth, V. and R.S. Bringhurst. 1984. 'Chandler'. Plant Patent 5262, 24 July. 